\title{
Online career counseling success: the role of hardiness and psychological capital
}

\author{
Nooshin Pordelan ${ }^{1} \cdot$ Simin Hosseinian ${ }^{1}$ (D)
}

Received: 26 February 2020 / Accepted: 20 November 2020 / Published online: 2 January 2021

(c) The Author(s), under exclusive licence to Springer Nature B.V. part of Springer Nature 2021

\begin{abstract}
Online career counseling is an important new horizon for vocational guidance. The present study investigates the role of online career counseling and of psychological capital and hardiness on career decision making. The research population included all Tehran students in 2019. After random selection, 30 students each were assigned into either the online counseling group or the control group. After online counseling, intervention students had higher scores than the control group on career decisionmaking. In the intervention group (but not the control group), students with higher hardiness and psychological capital had higher scores on career decision-making.
\end{abstract}

Keywords Hardiness · Psychological capital · Online career counseling

\section{Résumé}

\section{Succès de l'orientation professionnelle en ligne: Le rôle de la hardiesse et du capital psychologique}

L'orientation professionnelle en ligne représente un nouvel horizon important pour l'orientation professionnelle. La présente étude examine le rôle de l'orientation professionnelle en ligne, ainsi que du capital psychologique et la hardiesse dans le processus de décision de carrière. La population étudiée comprend tous les étudiants de Téhéran en 2019. Après une sélection aléatoire, 30 étudiant·e·s ont chacun été répartis soit dans le groupe de counseling en ligne, soit dans le groupe contrôle. Après avoir suivi le counseling en ligne, les étudiant.e.s du groupe d'intervention ont obtenus des résultats plus élevés que le groupe contrôle sur la prise de décision de carrière. Dans le groupe d'intervention (mais pas dans le groupe contrôle), les étudiant·e·s avec une plus grande hardiesse et capital psychologique ont obtenu des scores plus élevés sur la prise de décision de carrière.

Simin Hosseinian

Hosseinian@alzahra.ac.ir

Nooshin Pordelan

n.pordelan@alzahra.ac.ir

1 Department of Counseling, Faculty of Education and Psychology, Alzahra University, Tehran, Iran 


\section{Zusammenfassung}

Erfolg in der Online-Laufbahnberatung: Die Rolle der Widerstandsfähigkeit und des psychologischen Kapitals Die Online-Laufbahnberatung ist ein wichtiger neuer Horizont für die Laufbahnberatung

Die vorliegende Studie untersucht die Rolle der Online-Laufbahnberatung sowie des psychologischen Kapitals und der Widerstandfähigkeit bei der Entscheidungsfindung im Beruf. Die Stichprobe umfasste alle Teheraner Studierenden des Jahres 2019. Nach einer Zufallsauswahl wurden jeweils 30 Studierende der Online-Beratungsgruppe sowie der Kontrollgruppe zugeteilt. Nach der Online-Beratung hatte die Online-Beratungsgruppe höhere Werte im Bereich der Entscheidungsfindung im Beruf als die Kontrollgruppe. In der Online-Beratungsgruppe (nicht aber in der Kontrollgruppe) hatten Studierende mit höherer Widerstandsfähigkeit und höherem psychologischen Kapital höhere Werte im Bereich der Entscheidungsfindung im Beruf.

\section{Resumen}

Éxito de la orientación profesional on-line: El papel de la resistencia y el capital psicológico La orientación par el desarrollo de la carrera on-line supone un nuevo e importante horizonte para la orientación profesional

El presente estudio investiga el papel de la orientación profesional on-line y del capital psicológico y la resistencia en la toma de decisiones de carrera. La población investigada incluyó a todos los estudiantes de Teherán en 2019. Después de realizar un muestreo aleatorio, 30 estudiantes fueron asignados al grupo de orientación on-line o al grupo de control. Después de la orientación on-line, los estudiantes con los que se había realizado la intervención obtuvieron puntuaciones más altas que el grupo de control en la toma de decisiones de carrera profesional. En el grupo de intervención (pero no en el grupo de control), los estudiantes con mayor resistencia y capital psicológico obtuvieron mejores puntuaciones en la toma de decisiones sobre carrera profesional.

\section{Introduction}

The internet and digital technologies have been developed in the societies and were integrated with all aspects of people's life, such as workplace, education, and public and private services (Baturay \& Toker, 2019; Imamura et al., 2015; Pordelan et al., 2020). The youth constitute a wide range of internet users (Shields \& Behrman, 2000) and around 694 million people above 15 use internet that constitute $14 \%$ of people above 15 in the world. The US, with 152 million internet users over 15 , is the top one (Barak, 2007). According to the studies, in Iran, in 2001, there were 300,000 and in 2002, there were 1,550,000 internet users and now, there are over 3,000,000 users (Pashaei et al., 2009). This issue is more crucial for the young generation, because these individuals have less experience and also are dependent on the internet for important decision-makings in their lives (Bigdeli et al., 2016). According to studies on Iranian population, the youth constitute a large portion of the internet users of the country (Mousavi, 2020). The disadvantages of high internet use are investigated and confirmed by many researchers. However, the internet 
as a technology has advantages such as promoting career development (Pordelan et al., 2018), facilitating career adaptability (Teychenne et al., 2019), reducing psychological disorders (Christensen et al., 2014; Hodgins et al., 2019), teaching and learning (Korhonen et al., 2019; Lee \& Huang, 2018), and better career decisionmaking (Nota et al., 2016; Pordelan et al., 2020).

\section{Career counseling and career decision-making}

According to the American Counseling Association (ACA), counselling is a professional relationship that helps people, families, and various groups to achieve mental health, wellness, education, and career goals (Kaplan et al., 2014). Career counseling means helping people to discover their real stance, achieve self-awareness, and create a clear and unified picture about themselves and the world of work (Zunker, 2011) and these aspects have a large impact on career decision-making (Gati et al., 2019; Rogers et al., 2008; Ulas \& Yildirim, 2019). Career counseling is not dedicated to decision-making and includes many problems such as frustrations, disappointments due to the sense of redundancy, unemployment, managing relations with other people in the workplace, decision-making about returning to career or education and finding solutions to create a balance between various life roles (Kidd, 2006). Career counseling can help people to find a suitable profession and this can identify an environment in which the person can flourish (Baruch, 2004).

Career counseling is based on three paradigms of vocational guidance, career education, and life design (Savickas, 2012). Researchers believe that traditional approaches cannot account for challenges resulted from changes in the world of work and it is better to use new approaches in career counseling (Maree, 2015). In order to be successful in the course of changes in the world of work, it is necessary to have a good choice based on scientific principles (Bravo et al., 2017). Gati and Levin (2012) state that those students who are concerned about their future and learn decision-making skills, will have successful career development. In career studies, decision-making components are introduced as necessary tools to design career (Saka \& Gati, 2007) and through career decision-making, people create their unique life style (Lent, 2013). The importance of career decision-making is important in life as well as advancing social goals, so that with an appropriate career decision-making, a country can reach balance and satisfy necessary needs of the society (Rogers \& Creed, 2011).

\section{Career decision-making and online career counseling}

Career decision-making is one of the most important aspects in the lives of the youth that has long-term effects on their lives (Hou et al., 2019; Wang et al., 2018). Most of the people find it difficult and when they face such decisions, they seek help and career counseling to choose the option that has the most desirable results (Gati \& Levin, 2015).

The online career counseling technologies constitute one of the career counseling modes in which the possibility for the clients to have access to the online counseling 
increases and new types of support are provided. The internet can provide various modes of communication through emails, videoconferences, and multiple social media applications. These communication technologies have been used in various contexts of the online counseling such as workforce development, entrepreneurship education, career development, and learning development (Hooley et al., 2016).

The internet can provide a context for career counselors to provide services and the youth can take advantage of them (Pordelan et al., 2020). The online career counseling can function as a trustable tool and provide efficient information for counselors and those who need counseling services (Dozier et al., 2015). The inherent nature of the online career counseling and lack of presence in a social and faceto-face position opens the way to increase self-confident statement of the facts by the clients, which facilitate the online career counseling process (Pordelan et al., 2018). There is a lot of research evidence that in general, indicate the value and importance of the online counseling as well as the role of the internet in supporting the career development. In many studies conducted so far, the role of information technologies in counseling services has been addressed, but only a few studies have investigated the features and attributes of the users in the successful use of the services of these tools. For instance, Christensen et al. (2014); Nota et al. (2016); Severy (2008); have studied the effectiveness of online interventions; however, in Iran, as a developing country, a limited number of studies have been conducted in examining the individual characteristics of users in the success of online Career counseling, and therefore, this study may be a novel one.

\section{The role of hardiness and psychological capital in using online career counseling}

One of the variables that is highly related to the internet use is the personality traits (Stodt et al., 2018; Xiao et al., 2019). Psychological capital and hardiness are among the positive psychological traits that can have positive impacts on the performance of people in using the online services (Barber \& Harvey, 2019).

Psychological capital is defined as a belief in one's abilities to achieve success, hardiness in following the goals, giving positive emotions to the self and others, and tolerating the problems (Avey et al., 2006) and it is characterized by features such as self-efficacy, optimism, hope, and resilience. Psychological capital includes positive aspects of lives and is based on self-understanding, having goals to achieve success, and resistance when facing problems (Luthans \& Youssef-Morgan, 2017). Despite limited studies on the relationship between psychological capital and the online counseling, Barber and Harvey (2019) investigated the relationship between resilience as one of the components of psychological capital and the online learning. Also, Xie et al. (2006) investigated the role of resilience and motivation in the online learning and the results pointed to the positive impact of resilience on the online learning. Bressler and Bressler (2007) investigated the relationship between self-efficacy and learning in online classes and the results showed that self-efficacy leads to success in such classes.

Kobasa (1979) defined hardiness as a combination of beliefs about the self and the world that consists of the three components of commitment, control, and 
fighting. A person with strong commitment believes in the importance of who he is and what activity he performs. These people integrate with many aspects of their life such as occupation, family, and interpersonal relations. People who are strong at controlling things, they can see their life events predictable and controllable and believe that they can influence what happens around them through their efforts. People who have high fighting motivation, consider positive and negative situations that need adaptation as an opportunity for learning and development (Maddi, 1990). Despite limited studies on the relationship between hardiness and efficiency of the online career counseling, Abdollahi et al. (2018); Sheard (2009); Tho (2019) investigated the relationship between hardiness and better performance.

\section{The purpose of the present study}

Career counseling and use of the internet for it will be an inevitable necessity in the future of career services. The use of these technologies, especially the internet, eliminates the problems of the traditional methods in terms of providing access to the counseling and guidance centers and gives valuable and classified information from a wide range of unscientific information to the clients. In fact, the use of technology facilitates access to do the services and it provides an environment in which people interact with each other and exchange the required career information and discuss in the right atmosphere. Therefore, according to the increasing use of the internet among the youth and their needs for better career decision-making, this study aims to test the following hypotheses: 1 . Psychological capital has a significant role in the youth's use of the online career counseling; 2 . Hardiness has a significant role in the youth's use of the online career counseling.

\section{Method}

\section{Participants}

In this study, 60 students were selected as the sample of the study, including two groups of the online counseling (15 males and 15 females; $M_{\text {age }}=24.40$ years; $S D=2.17$ ) and the control ( 15 males and 15 females; $M_{\text {age }}=24.76$ years; $S D=2.19$ ). The selected sample included junior and senior B.A students, because these students are close to their graduation and are more concerned about the labor market. The participants in this study were selected from different fields of studies. In Iran, if students pass the entrance exam, they can enter university at the age of 19 including four academic years. The students in the third and fourth years at least should be 22 and 23 years old, respectively.

The intervention group, in addition to completing career decision-making questionnaire, completed psychological capital and hardiness questionnaire at the pretest and according to the hardiness mean score of 130 in the intervention group, people who obtained scores above the mean, were placed in the group of subjects with high hardiness and those who obtained scores below 130 were placed in the group of 
subjects with low hardiness. Psychological capital mean in the intervention group was 53 and those who obtained scores above this mean were placed in the group of subjects with high psychological capital and those who obtained scores below 53 were placed in the group of subjects with low psychological capital. Demographic information of the participants is presented in Table 1.

\section{Procedure}

This study is a quasi-experimental study with a pretest-posttest design and a followup with the control group. The quasi-experimental design is used when it is not possible to use experimental designs and the researcher experiences limitations such as selection and assigning the subjects into different groups randomly.

To conduct this study, first one of the universities in Tehran was selected randomly and interested students were invited to participate in the workshop aiming to prepare the youth to enter the labor market. The volunteer students registered to participate in the online workshop and after specifying the interests of people to participate in the training course, according to Gall et al. (1996), 30 students were selected randomly for each group and they were assigned into the research groups. The intervention groups received career counseling in five sessions (90 min) as online mode. The interval between post-test and follow-up included 30 days.

To observe ethical considerations in the current study, it was explained that the participants are participating in a study that aims to investigate the effect of the online career counseling on career decision making and they were ensured that their personal information will remain confidential and when the study is over, questionnaires and data will be deleted and the results will be investigated at the group scale and they can cancel the process whenever they want. Prior to the training course, the subjects in the research groups completed career decision making questionnaire and after 5 sessions, the posttest was administered for all respondents. Also, the followup test was administered once to determine the consistency of the independent variable. No intervention existed for the participants in the control group until the end of interventions for the participants in the experimental group and it was explained to the participants in the control group that they are participating in a study to promote career decision-making abilities. In addition, to observe ethical considerations, all participants in the control group received gifts at the end of the study to appreciate their participation in the online sessions.

A summary of the counseling training course based on the life design approach Savickas (2015) is presented here.

Session one: explaining about privacy of information, completing the questionnaires, providing information about the importance of career decision-making and challenges of transition from university to work, preparing a list of works that they have done, preparing a list of works that they are thinking about. Session two: presenting a summary of the previous session, reviewing the homework in the previous session, engaging students and creating concerns and motivation, encouraging them toward narrating life stories, asking seven fundamental questions of Savickas's career interview. Session three: a quick review and presenting a summary of the 


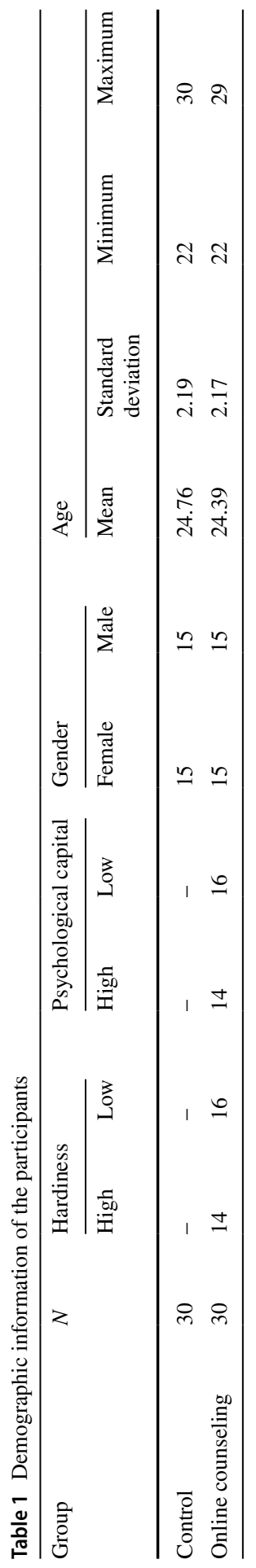


previous session. To discover life story and its theme, the statements of the students were investigated deeply and it was found that what students have used to answer the previous questions? What titles they have used? Why this memory has been stated among all other memories? Moreover, in this session, implicit issues and features in the students' responses were discovered.

Session four: reviewing the homework and clarifying the ambiguities, presenting career personality discovery table, reviewing life them and career personality, students, help to write success formula through completing the sentences, encouraging the students to rewrite their story. Session five: committing the students to their decisions, determining goals for the next chapter of career, and completing post-test questionnaires. After appreciating their active participation, the next sessions for the follow-up test were determined.

Before the counseling sessions, the students were receiving messages every week to refer to the website. Then, every session was starting by a video and presenting explanations about the session. In order to have structured session and avoid boring sessions, a session was divided into 4 to 6 sessions and users' participation was needed in every session. For example, session one was divided into five sections and in its first section, a video existed about the privacy of information and completing the questionnaires and the link of online questionnaires was given to the students. After completing the questionnaires, the students could observe the second part of the first session. In the second part of the first session, another video existed about activities suitable for life design paradigm. These points were considered in the online counseling sessions: 1 . Sending message and email to remind the students to refer to the website 2. Presenting short videos to prevent users from getting tired 3. Using graphic images to transfer career counseling information to the students 4 . Structuring information and website career bank consistent with each session and avoid to leave students in the middle of a large amount of information 5. In all session, the students could use digital sources to do homework (e.g. they could present their life story as a PowerPoint) 6. Availability of counselors in every session and possibility to have online conversation 7. Coordinating the users' profile with previous career sessions (e.g. the users were asked to place their life motto into their profile and allow other users to observe it).

\section{Instruments}

\section{Career decision scale (CDS) by Osipow et al. (1976)}

This scale was designed by Osipow et al. (1976) and translated and validated in Iran by researchers. The reliability of this scale in Iran is examined by Cronbach's alpha as .83 (Parishany \& Nilforooshan, 2015). This scale contains 18 questions and is resulted from two scales that are decision making scale and indecision scale. First of all, two questions assess indecision of students and questions 3-18 focus on career decision making of the students. Higher scores in this scale indicate better career decision making. 


\section{The hardiness scale (HS) by Kobasa}

This scale includes 45 items that in addition to the general hardiness score, there are three subscales of commitment (15 questions), challenge (15 questions), and control (15 questions). The responses are according to the Likert scale from 0 (absolutely false) to 3 (absolutely true). The scores of 39 items are reverse that 0 is "absolutely true" and 3 is "absolutely false". This scale has acceptable reliability and validity and it is examined by different researchers (Bartone et al., 1989; Janda, 2000). This scale has been validated in an Iranian sample and its psychometric traits are as follows: the Cronbach's alpha of .80 to .88 for commitment, .58 to .94 for control, .89 to .95 for challenge, and .87 to .94 for hardiness that indicate acceptable internal consistency of the scale (Hasel \& Besharat, 2011).

\section{Psychological capital questionnaire (PCQ)}

This questionnaire includes 24 questions and 4 subscales of hope, resilience, optimism, and self-efficacy in which each subscale includes 6 items and the responses are based on the 6-point Likert scale (from absolutely disagree to absolutely agree). Questions 1-6 are related to self-efficacy, questions 7-12 are related to hope, questions 13-18 are related to resilience, and questions 19-24 are related to optimism (Luthans et al., 2007). To obtain psychological capital score, the score of each subscale is obtained separately and then, their sum is considered as the total psychological capital score. Luthans et al. (2007) in two studies reported acceptable construct validity for this questionnaire. In the first study, chi-square (422.7), root mean square residual (.04), and goodness of fit (.93), and in the second study, chi-square (448.2), root mean square residual (.04), and goodness of fit (.92) were obtained. McGee (2011) reported Cronbach's alpha for self-efficacy, hope, resilience, and optimism as $.88, .86, .83$, and .83 , respectively. This questionnaire was translated in Iran by Golparvar and its face validity, content validity, and reliability are confirmed. The reported reliability in Golparvar's study for self-efficacy, hope, resilience, and optimism are .91, .89, .83, and .70, respectively (Golparvar \& Jafari, 2013).

\section{The career counseling website}

This website is written with PHP language and has three distinct control panels and can be found in Persian language on www.careercounseling.ir. This website has extensions for better communication between counselors as well as users and counselors and other users. The face validity and the construct validity of the website were confirmed by 40 experts (20 career counseling experts and 20 software engineering experts). 


\section{Results}

To test the research hypotheses, repeated measures were used. First, descriptive characteristics of the research variables in different groups are presented.

According to Table 2, the intervention group (the online career counseling) outperformed the control group in terms of career decision making. The group with higher hardiness compared to the group with lower hardiness obtained higher mean in career decision making and the group with high psychological capital obtained higher mean than the group with low psychological capital. To investigate the significant difference between the groups, repeated measures were used (Table 2).

The results of counseling interventions and their effects on career decisionmaking showed that a significant difference regarding career decision making exists between the two groups of the study (Wilks's lambda $=.22, F(2,57)=96.95$, $p=.001$.). Mauchly's test of sphericity indicated that the assumption of sphericity has been violated $\left(\chi^{2}(2)=25.33, p<.001\right)$; therefore, a Greenhouse-Geisser correction was used. Time had a significant effect on career decision making, $F(1.47$, $85.37)=155.45, p<.001, \eta_{\mathrm{p}}^{2}=.72$ ).

The results of hardiness effects on career decision-making showed that a significant difference regarding career decision-making exists between the two groups (Wilks's lambda $=.73, F(2,27)=4.97, p=.001$ ). Mauchly's test of sphericity indicated that the assumption of sphericity has been violated $\left(\chi^{2}(2)=18.43, p<.001\right)$; therefore, a Greenhouse-Geisser correction was used. Time had a significant effect on career decision-making, $\left.F(1.33,37.46)=6.60, p<.008, \eta_{\mathrm{p}}{ }^{2}=.19\right)$.

The results of psychological capital effects on career decision making showed that a significant difference regarding career decision making exists between the two groups (Wilks's lambda $=.78, F(2,27)=3.81, p=.001$ ). Mauchly's test of sphericity indicated that the assumption of sphericity has been violated $\left(\chi^{2}(2)=17.29\right.$, $p<.001)$; therefore, a Greenhouse-Geisser correction was used. Time had a significant effect on career decision making, $F(1.35,38.02)=6.27, p<.01, \eta_{\mathrm{p}}{ }^{2}=.18$ ).

In Figure 1, Diagram (a) the mean of career decision-making in the experimental group and the control group in the pre-test, post-test, and follow-up is presented. Diagram (b) the mean of career decision-making in the online group with high and low hardiness is presented. Diagram (c) the mean of career decision-making in the online group with high and low psychological capital is presented.

In Figure 1, Diagram (a) shows that the experimental group has obtained larger mean than the control group in career decision-making in the post-test and followup. Diagram (b) shows that the mean of career decision-making in the group with high hardiness in the post-test and follow-up is larger than the group with low hardiness. Diagram (c) shows that the mean of career decision-making in the group with high psychological capital in the post-test and follow-up is larger than the group with low psychological capital. 


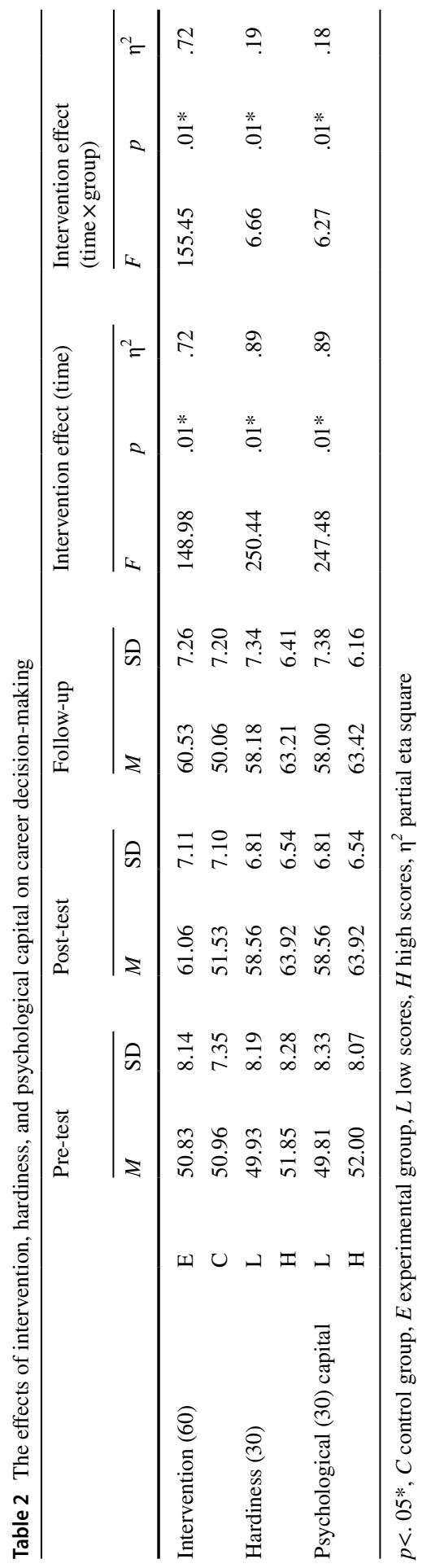




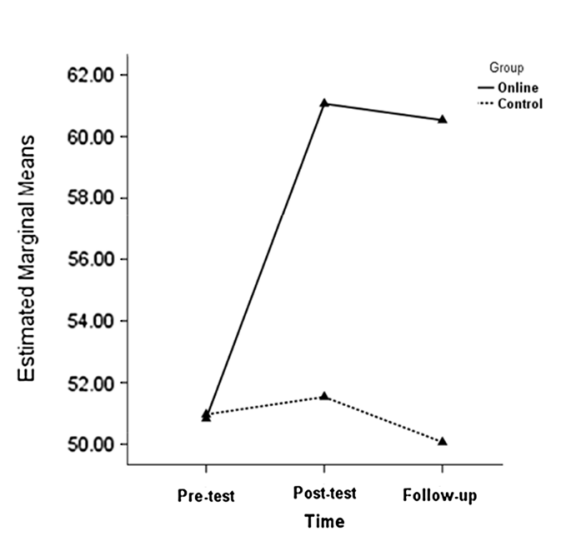

(a) Career decision making mean of the intervention group (the online group) and the control group

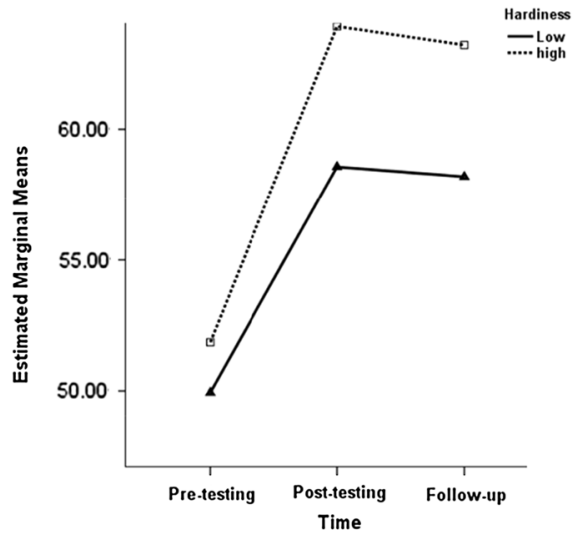

(b) Career decision making mean of the groups with high and low hardiness

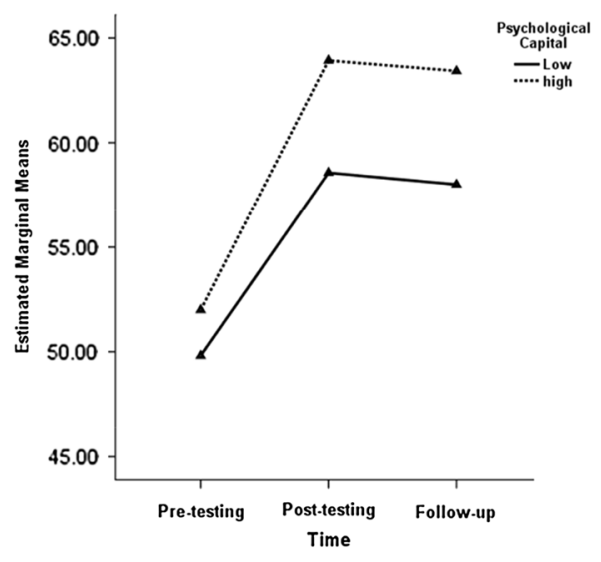

(c) Career decision making mean of the groups with high and low psychological capital

Figure 1 changes in career decision-making

\section{Discussion}

This study aimed to investigate the effect of the online counseling on career decision-making and the role of psychological capital and hardiness in career decisionmaking of the youth. The research findings showed that the online career counseling has a significant effect on career decision-making of the youth. In explaining the findings, it can be said that the online career counseling can be efficient when it has therapeutic factors such as face-to-face counseling. Counseling groups and online support groups should have therapeutic factors similar to the stated cases by Yalom (1995) in the face-to-face groups. These cases include sense of belonging and 
acceptance, willingness and need to disclose personal information, honesty about feelings, interest in others and accepting them, honest intentions and support for the group, personal importance, sense of stability, and hope for the group members. On the website, to create the sense of belonging and acceptance, facilities such as group formation are given to the users and they can create groups through the internet and talk about different issues. Therefore, they can create groups and take advantage of different views. However, since these tools and other technical services help people in certain cases, this does not mean that the importance of counseling to help the clients is declined. The most effective counseling is the interactive process between the clients and the counselor and in the online career counseling website, it is possible for users to interact with the counselor whenever they want.

Precision and accuracy are needed in assessing the available information in the internet network. In some cases, the websites may encourage the authorities for decision making where the counselor should point out that the results will be beneficial if the counselor and the clients are involved in the decision-making process. On the online career counseling website, with classified information and constant supervision of the counselors over the career information, the possibility of making a mistake is minimized. One of the main shortcomings of communication tools in the past was the existence of a one-way and concentrated relationship, so that it was not possible to create connection and receive feedback, but on the online career counseling website, with modern technologies, it is possible to create connections between the counselor and the user. In this condition, immediately after receiving the message, the users can reflect their views and comments.

On the online career counseling website in this study, an exceptional opportunity was given to the counselors and the clients to see what happens in counseling discourses when discussions are over and they visit the online website and see the archives. This makes them have more accurate information about their talks or investigate and complete their activities. However, in the traditional relationships of counseling, discourses were always hidden and any attempt to disclose them was dependent on the participant's willingness and on the recordings by the counselor directly in interactions that may influence the nature of talks. Also, the online career counseling website provided a source of data, where it is possible to have a full access to them. These data are valuable, because they provide the necessary context to discuss the quality of interactions and in this case, it can be determined whether the discussions are desirable or not. The results of findings of this section about the effect of the online counseling on career decision-making of the youth are consistent with Hooley (2012) who investigated the effect of the internet on the career development, with Rutten et al. (2016), who investigated the effect of social networks on career skills, with Chen et al. (2018), who investigated the effect of the online training on career adaptability, with Pordelan et al. (2018), who investigated the effect of the online intervention on career development of students, and with Denzinger et al. (2019), who studied the online interventions for families.

The results also showed that people with high resilience and psychological capital, obtain better scores in career decision making. In explaining the findings of this hypothesis, it can be said that hardiness protects the person against external and internal pressures and prepares him or her to face problems. They not only do 
not sacrifice themselves for problems, but do their best to solve such problems and believe that they can make changes in themselves and their way. However, people with low hardiness, because of little hope, avoid attempts and face many problems on their way. The psychological features of hardiness, such as curiosity, tendency towards interesting and meaningful experiences, self-expression, being energetic, and this fact that changes in life are natural, can lead to positive changes in the person. On the online counseling website, the group with higher hardiness obtained better scores in career decision making.

One of the components of psychological capital is self-efficacy. As Stimpfel (2013) states, one source to enhance career decision making self-efficacy in universities is classes, workshops, mentors, computer-based interventions, and guidance by the faculty members and in this study, workshops and computer-based interventions were used. It should be noted that if these interventions are based on standard principles and packages, they can be efficient. For this reason, the counseling course with increased self-knowledge leads to the development of self-awareness and awareness of the environment and if a person can access these sources, they can experience better decision-making self-efficacy; for example, when the person obtains more information about his values, self-knowledge increases and this person tries to consider his values in career decision making and this promotes career decision-making. Moreover, another source of self-efficacy is social motivation. It means a person is encouraged by others and receives indirect and direct awards for their behaviors and this assessment by others leads to the internalization of that behavior and increase motivation. These encouragements are created easily through the online mode. Also, the internet and its environment provides an ideal social environment for users in which people can share their achievements with others; for example, by receiving positive feedbacks from other users or showing self-achievements to others through the online mode, which is done quickly, their learning becomes a social reality, by which they can feel the sense of success. Many people express their thoughts and feelings easily when they are not under the supervision of others and, as a result, they express their problems easily. For this reason, online connections can be effective in the career counseling. This is consistent with results obtained by Ferreira et al. (2013), who investigated the relationship between career adaptability and career satisfaction with hardiness, with Huang (2015), who predicted employability and career decision-making self-efficacy according to hardiness, with Cenciotti et al. (2017), who investigated the relationship between psychological capital and career success, and Safavi and Bouzari (2019) who investigated the relationship between career adaptability and psychological capital.

Life in this era is closely related to digital changes and dispersions that people spend a lot of time on using technology and information technology, whether positive or negative. The movement of the existing communities toward the increasing use of online resources has transformed traditional guidance and counseling. This led to increased needs and use of flexible approaches such as life design paradigm that is consistent with changes in the digital world. The researchers in this study concluded that the online career counseling with life design paradigm influences career decision-making of the students. These findings are important from several aspects and can help the future studies. First, life design paradigm can match it with digital 
technology and it is possible to use digital facilities in this paradigm. For example, the use of digital storytelling that many studies are conducted on it (Björninen et al., 2020; Van Laer et al., 2019)can match with life design paradigm very well. This match is more observed about storytelling and seven fundamental questions of Savickas's career interview. Second, the existing condition due to Covid-19 spread has intensified the need to use digital technology and stay at home more than ever and it is needed to conduct more studies on the online career counseling self-efficacy. Third, this study has investigated the success of online counseling according to some personality traits and it is needed to conduct more studies to understand if there is other factors that can promote the success of online career counseling.

\section{Conclusion}

The present study aimed to investigate the impact of hardiness and psychological capital on the success of online career counseling. To determine the success of online career counseling, the participants were randomly assigned to the experiment and control groups. Comparison of online and control groups showed that online career counseling was able to significantly increase group career decision-making. Then, the effect of psychological capital and hardiness on the success rate of the online group was examined. The results showed that people with more psychological capital and tenacity scored better on career decision-making. Thus, it can be said that individual characteristics can affect the success or failure of online career counseling.

\section{Future work}

Researchers in this study attempted to examine the role of hardiness and psychological capital in the success of online career counseling, and encountered questions that could greatly aid future research in online career counseling. Future works can show if, in addition to the individual characteristics, participants' skills, including reading and writing skills, can be influenced by better use of online career. In addition, one can try to show if this research can be explored at different ages to find a suitable age for better use of the online career counseling. In addition, it can be attempted to consider the role of online career counseling in helping people with physical disabilities or mental disorders.

\section{Limitations}

This study suffers from limitations. First, this study is conducted on the young students and more studies are needed to generalize the results to older people or children. Second, this study is a cross-sectional study in 2019. Therefore, it is necessary to conduct a longitudinal study and analyze its results in a long-term run. Third, this study has investigated two variables of psychological capital and hardiness in students' use of the online career counseling and it is needed to investigate other traits and moderating and intervening variables such as self-efficacy. 


\section{References}

Abdollahi, A., Carlbring, P., Vaez, E., \& Ghahfarokhi, S. A. (2018). Perfectionism and test anxiety among high-school students: The moderating role of academic hardiness. Current Psychology, 37(3), 632639. https://doi.org/10.1007/s12144-016-9550-z.

Avey, J. B., Patera, J. L., \& West, B. J. (2006). The implications of positive psychological capital on employee absenteeism. Journal of Leadership \& Organizational Studies, 13(2), 42-60. https://doi. org/10.1177/10717919070130020401.

Barak, A. (2007). Emotional support and suicide prevention through the Internet: A field project report. Computers in Human Behavior, 23(2), 971-984. https://doi.org/10.1016/j.chb.2005.08.001.

Barber, W., \& Harvey, J. (2019). Online learning success the moderating role of hardiness, resilience, grit and growth mindset a theoretical overview. In Global learn.

Bartone, P. T., Ursano, R. J., Wright, K. M., \& Ingraham, L. H. (1989). The impact of a military air disaster on the health of assistance workers. Journal of Nervous and Mental Disease, 177(6), 317-328. https://doi.org/10.1097/00005053-198906000-00001.

Baruch, Y. (2004). Managing careers: Theory and practice. Pearson Education.

Baturay, M. H., \& Toker, S. (2019). Internet addiction among college students: Some causes and effects. Education and Information Technologies, 24(5), 2863-2885. https://doi.org/10.1007/s10639-01909894-3.

Bigdeli, Z., Hayati, Z., Heidari, G. R., \& Jowkar, T. (2016). Place of internet in health information seeking behavior: Case of young Internet users in Shiraz. Human Information Interaction, 3(1), 68-78.

Björninen, S., Hatavara, M., \& Mäkelä, M. (2020). Narrative as social action: A narratological approach to story, discourse and positioning in political storytelling. International Journal of Social Research Methodology, 23(4), 437-449. https://doi.org/10.1080/13645579.2020.1721971.

Bravo, J., Seibert, S. E., Kraimer, M. L., Wayne, S. J., \& Liden, R. C. (2017). Measuring career orientations in the era of the boundaryless career. Journal of Career Assessment, 25(3), 502-525. https:// doi.org/10.1037/a0021452.

Bressler, L. A., \& Bressler, M. E. (2007). The relationship between self-esteem and self-efficacy among distance learning students in Accounting Information Systems online classes. International Journal of Innovation and Learning, 4(3), 274-289.

Cenciotti, R., Alessandri, G., \& Borgogni, L. (2017). Psychological capital and career success over time: The mediating role of job crafting. Journal of Leadership \& Organizational Studies, 24(3), 372384. https://doi.org/10.1177/1548051816680558.

Chen, C., Liu, T., \& Chen, Y. (2018). A study of career adaptability and work engagement of online teachers in the E-education industry: The mechanism of job insecurity and employability. Proceedings of the 6th International Conference on Information and Education Technology.

Christensen, H., Batterham, P., \& Calear, A. (2014). Online interventions for anxiety disorders. Current Opinion in Psychiatry, 27(1), 7-13. https://doi.org/10.1097/YCO.0000000000000019.

Denzinger, A., Bingisser, M.-B., Ehrbar, V., Huggenberger, H. J., Urech, C., Woessmer, B., et al. (2019). Web-based counseling for families with parental cancer: Baseline findings and lessons learned. Journal of Psychosocial Oncology, 37(5), 599-615. https://doi.org/10.1002/pon.4679.

Dozier, V. C., Sampson, J. P., Jr., Lenz, J. G., Peterson, G. W., \& Reardon, R. C. (2015). The impact of the Self-Directed Search Form R Internet version on counselor-free career exploration. Journal of Career Assessment, 23(2), 210-224. https://doi.org/10.1177/1069072714535020.

Ferreira, N., Coetzee, M., \& Masenge, A. (2013). Psychological career resources, career adaptability and hardiness in relation to job embeddedness and organizational commitment. Journal of Psychology in Africa, 23(1), 31-40. https://doi.org/10.1080/14330237.2013.10820591.

Gall, M. D., Borg, W. R., \& Gall, J. P. (1996). Educational research: An introduction (6 ed.). Longman Publishing.

Gati, I., \& Levin, N. (2012). The stability and structure of career decision-making profiles: A 1-year follow-up. Journal of Career Assessment, 20(4), 390-403. https://doi.org/10.1177/106907271244889 2 .

Gati , I., \& Levin, N. (2015). Using information and communication technology in delivering career interventions. APA handbook of career intervention. In P. J. Hartung, M. L.Savickas, \& W. B. Walsh (Eds.) APA handbook of career intervention (Vol. 2, pp. 193-208). APA Books.

Gati, I., Levin, N., \& Landman-Tal, S. (2019). Decision-making models and career guidance. In International handbook of career guidance (pp. 115-145). Springer. 
Golparvar, M., \& Jafari, M. (2013). Prediction of psychological capital through components of spirituality among nurses. Iranian Journal of Psychiatric Nursing, 1(3), 35-44.

Hasel, K. M., \& Besharat, M. A. (2011). Relationship of perfectionism and hardiness to stress-induced physiological responses. Procedia-Social and Behavioral Sciences, 30, 113-118.

Hodgins, D. C., Cunningham, J. A., Murray, R., \& Hagopian, S. (2019). Online self-directed interventions for gambling disorder: Randomized controlled trial. Journal of Gambling Studies, 35(2), 635651. https://doi.org/10.1007/s10899-019-09830-7.

Hooley, T. (2012). How the internet changed career: Framing the relationship between career development and online technologies. Journal of the National Institute for Career Education and Counselling, 29(1), 3-12.

Hooley, T., Hutchinson, J., \& Neary, S. (2016). Ensuring quality in online career mentoring. British Journal of Guidance \& Counselling, 44(1), 26-41. https://doi.org/10.1080/03069885.2014.1002385.

Hou, C., Wu, Y., \& Liu, Z. (2019). Career decision-making self-efficacy mediates the effect of social support on career adaptability: A longitudinal study. Social Behavior and Personality: An International Journal, 47(5), 1-13. https://doi.org/10.2224/sbp.8157.

Huang, J.-T. (2015). Hardiness, perceived employability, and career decision self-efficacy among Taiwanese college students. Journal of Career Development, 42(4), 311-324. https://doi.org/10.1177/08948 45314562960 .

Imamura, K., Kawakami, N., Furukawa, T. A., Matsuyama, Y., Shimazu, A., Umanodan, R., et al. (2015). Effects of an internet-based cognitive behavioral therapy intervention on improving work engagement and other work-related outcomes: An analysis of secondary outcomes of a randomized controlled trial. Journal of Occupational and Environmental Medicine, 57(5), 578-584. https://doi. org/10.1097/JOM.0000000000000411.

Janda, L. (2000). The psychologist's book of personality tests: 24 revealing tests to identify and overcome your personal barriers to a better life. Wiley.

Kaplan, D. M., Tarvydas, V. M., \& Gladding, S. T. (2014). 20/20: A vision for the future of counseling: The new consensus definition of counseling. Journal of Counseling \& Development, 92(3), 366372. https://doi.org/10.1002/j.1556-6676.2014.00164.x.

Kidd, J. M. (2006). Understanding career counselling: Theory, research and practice. Sage.

Kobasa, S. C. (1979). Stressful life events, personality, and health: an inquiry into hardiness. Journal of Personality and Social Psychology, 37(1), 1. https://doi.org/10.1037/0022-3514.37.1.1.

Korhonen, A.-M., Ruhalahti, S., \& Veermans, M. (2019). The online learning process and scaffolding in student teachers' personal learning environments. Education and Information Technologies, 24(1), 755-779. https://doi.org/10.1007/s10639-018-9793-4.

Lee, S. J., \& Huang, K. (2018). Online interactions and social presence in online learning. Journal of Interactive Learning Research, 29(1), 113-128.

Lent, R. W. (2013). Career-life preparedness: Revisiting career planning and adjustment in the new workplace. The Career Development Quarterly, 61(1), 2-14. https://doi.org/10.100 2/j.2161-0045.2013.00031.x.

Luthans, F., Avolio, B. J., Avey, J. B., \& Norman, S. M. (2007). Positive psychological capital: Measurement and relationship with performance and satisfaction. Personnel Psychology, 60(3), 541-572. https://doi.org/10.1111/j.1744-6570.2007.00083.x.

Luthans, F., \& Youssef-Morgan, C. M. (2017). Psychological capital: An evidence-based positive approach. Annual Review of Organizational Psychology and Organizational Behavior, 4(1), 339366. https://doi.org/10.1146/annurev-orgpsych-032516-113324.

Maddi, S. R. (1990). Issues and interventions in stress mastery. Mc Graw.

Maree, J. G. (2015). Life themes and narratives. In P. J. Hartung, M. L. Savickas , \& W. B. Walsh (Eds.), APA handbook of career intervention (Vol. 2, pp. 225-239). American Psychological Association. https://doi.org/10.1037/14439-005.

McGee, E. A. (2011). An examination of the stability of positive psychological capital using frequencybased measurement Tennessee - Knoxville]. Retrieved from http://trace.tennessee.edu/utk_gradd iss/999.

Mousavi, S.V.-A. (2020). Prevalence of Internet addiction and the Status of the use of virtual social networks in Iranian Teenagers and Youths in 2018. Journal Military Medicine, 22(3), 281-288. https:// doi.org/10.1002/j.1556-6676.2014.00164.x.

Nota, L., Santilli, S., \& Soresi, S. (2016). A life-design-based online career intervention for early adolescents: Description and initial analysis. The Career Development Quarterly, 64(1), 4-19. https://doi. org/10.1002/cdq. 12037 . 
Osipow, S., Carney, C., Winer, J., Yanico, B., \& Koschier, M. (1976). The career decision scale. Psychological Assessment Resources.

Parishany, N., \& Nilforooshan, P. (2015). Career indecision in boys: The role of individual factors and parenting styles. Knowledge \& Research in Applied Psychology, 15(3), 55-63.

Pashaei, F., Nikbakhtazad, N., \& TavakoliL, K. (2009). Young people experience of living with internet: A qualitative study. Journal of Behavioral Sciences, 2(4), 333-337.

Pordelan, N., Sadeghi, A., Abedi, M. R., \& Kaedi, M. (2018). How online career counseling changes career development: A life design paradigm. Education and Information Technologies, 23(6), 26552672. https://doi.org/10.1007/s10639-018-9735-1.

Pordelan, N., Sadeghi, A., Abedi, M. R., \& Kaedi, M. (2020). Promoting student career decision-making self-efficacy: An online intervention. Education and Information Technologies, 25(2), 985-996. https://doi.org/10.1007/s10639-019-10003-7.

Rogers, M. E., \& Creed, P. A. (2011). A longitudinal examination of adolescent career planning and exploration using a social cognitive career theory framework. Journal of Adolescence, 34(1), 163172. https://doi.org/10.1016/j.adolescence.2009.12.010.

Rogers, M. E., Creed, P. A., \& Glendon, A. I. (2008). The role of personality in adolescent career planning and exploration: A social cognitive perspective. Journal of Vocational Behavior, 73(1), 132142. https://doi.org/10.1016/j.jvb.2008.02.002.

Rutten, M., Ros, A., Kuijpers, M., \& Kreijns, K. (2016). Usefulness of social network sites for adolescents' development of online career skills. Journal of Educational Technology \& Society, 19(4), $140-150$.

Safavi, H. P., \& Bouzari, M. (2019). The association of psychological capital, career adaptability and career competency among hotel frontline employees. Tourism Management Perspectives, 30, 65-74. https://doi.org/10.1016/j.tmp.2019.02.001.

Saka, N., \& Gati, I. (2007). Emotional and personality-related aspects of persistent career decisionmaking difficulties. Journal of Vocational Behavior, 71(3), 340-358. https://doi.org/10.1016/j. jvb.2007.08.003.

Savickas, M. L. (2012). Life design: A paradigm for career intervention in the 21st century. Journal of Counseling \& Development, 90(1), 13-19. https://doi.org/10.1111/j.1556-6676.2012.00002.x.

Savickas, M. L. (2015). Life-design counseling manual. Rootstown, OH: Author.

Severy, L. E. (2008). Analysis of an online career narrative intervention: "What's my story?" The Career Development Quarterly, 56(3), 268-273. https://doi.org/10.1002/j.2161-0045.2008.tb00041.x.

Sheard, M. (2009). Hardiness commitment, gender, and age differentiate university academic performance. British Journal of Educational Psychology, 79(1), 189-204. https://doi.org/10.1348/00070 9908 X304406.

Shields, M. K., \& Behrman, R. E. (2000). Children and computer technology: Analysis and recommendations. The future of children. https://doi.org/10.2307/1602687.

Stimpfel, S. (2013). An unconventional path towards integration: A study of low-income community college students' career decision-making self-efficacy beliefs.

Stodt, B., Brand, M., Sindermann, C., Wegmann, E., Li, M., Zhou, M., et al. (2018). Investigating the effect of personality, internet literacy, and use expectancies in internet-use disorder: A comparative study between China and Germany. International Journal of Environmental Research and Public Health, 15(4), 579. https://doi.org/10.3390/ijerph15040579.

Teychenne, M., Parker, K., Teychenne, D., Sahlqvist, S., Macfarlane, S., \& Costigan, S. (2019). A prepost evaluation of an online career planning module on university students' career adaptability. Journal of Teaching and Learning for Graduate Employability, 10(1), 42.

Tho, N. D. (2019). Business students' hardiness and its role in quality of university life, quality of life, and learning performance. Education Training. https://doi.org/10.1108/ET-03-2018-0068.

Ulas, O., \& Yildirim, I. (2019). Influence of locus of control, perceived career barriers, negative affect, and hopelessness on career decision-making self-efficacy among Turkish university students. International Journal for Educational and Vocational Guidance, 19(1), 85-109. https://doi.org/10.1007/ s10775-018-9370-9.

Van Laer, T., Feiereisen, S., \& Visconti, L. M. (2019). Storytelling in the digital era: A meta-analysis of relevant moderators of the narrative transportation effect. Journal of Business Research, 96, 135146. https://doi.org/10.1016/j.jbusres.2018.10.053.

Wang, J., Guo, R., Liu, M., Zhang, X., Ren, L., Sun, M., \& Tang, S. (2018). Career decision-making selfefficacy and professional commitment among master nursing students. Western Journal of Nursing Research, 40(3), 327-345. https://doi.org/10.1177/0193945916682236. 
Xiao, J., Li, D., Jia, J., Wang, Y., Sun, W., \& Li, D. (2019). The role of stressful life events and the Big Five personality traits in adolescent trajectories of problematic Internet use. Psychology of Addictive Behaviors, 33(4), 360. https://doi.org/10.1037/adb0000466.

Xie, K., Debacker, T. K., \& Ferguson, C. (2006). Extending the traditional classroom through online discussion: The role of student motivation. Journal of Educational Computing Research, 34(1), 67-89. https://doi.org/10.2190/7BAK-EGAH-3MH1-K7C6.

Yalom, I. D. (1995). The theory and practice of group psychotherapy. Basic books (AZ).

Zunker, V. (2011). Career counseling: A holistic approach. Nelson Education.

Publisher's Note Springer Nature remains neutral with regard to jurisdictional claims in published maps and institutional affiliations. 